\title{
Protective effect of methanolic and flavonoid-rich leaf extracts of Synsepalum dulcificum (Danielli) on lead-acetate-induced toxicity in Wistar albino rats
}

Tajudeen O. Obafemi1 ${ }^{*}$, Amos Onasanya ${ }^{1}$, Akinwunmi Adeoye ${ }^{2}$, John A. Falode ${ }^{2}$, David J. Daniel ${ }^{1}$, Ehizode F. Irefo ${ }^{1}$, Adeleke O. Ojo ${ }^{1}$, Adewale Fadaka ${ }^{1}$, Olakunle B. Afolabi ${ }^{1}$, Joseph O. Awe ${ }^{1}$, Benjamin O. Omiyale ${ }^{1}$

${ }^{1}$ Biochemistry Programme, Department of Chemical Sciences, Afe Babalola University, Ado-Ekiti, Nigeria.

${ }^{2}$ Department of Biochemistry, Federal University, Oye-Ekiti, Nigeria.

\begin{tabular}{l}
\hline ARTICLE INFO \\
\hline Received on: $27 / 08 / 2018$ \\
Accepted on: $11 / 12 / 2018$ \\
Available online: 08/05/2019 \\
\hline Key words: \\
Glutathione, \\
malondialdehyde, vitamin, \\
flavonoid, biochemical.
\end{tabular}

\begin{abstract}
The present study aims to evaluate the protective effect of methanolic leaf extract and flavonoid-rich leaf extract of Synsepalum dulcificum on lead-acetate-induced toxicity in Wistar albino rats. Forty-five animals were distributed into nine groups with five animals apiece. Group 1 served as the control and was given only distilled water throughout the course of the study. Group 2 served as the lead-induced group and was administered $50 \mathrm{mg} / \mathrm{kg}$ lead-acetate. Groups 3-8 were co-administered $50 \mathrm{mg} / \mathrm{kg}$ lead-acetate and various doses of the extracts. Group 9 was administered $40 \mathrm{mg} / \mathrm{kg}$ vitamin C in addition to $50 \mathrm{mg} / \mathrm{kg}$ lead-acetate. The study lasted for 14 days. Standard procedures were used to evaluate the hematological indices, serum total protein, urea, creatinine, as well as marker enzymes in liver and kidney of the animals. Malondialdehyde levels, superoxide dismutase, and glutathione-s-transferase activities were also estimated in the tissues. The results showed that the extracts, especially the high doses, significantly $(p<0.05)$ ameliorated the harmful effects of lead administration in the liver and kidney as well as in the hematological indices. The extract could, therefore, be considered as having protective effect on lead-induced toxicity in Wistar albino rats.
\end{abstract}

\section{INTRODUCTION}

Lead $(\mathrm{Pb})$ is a very toxic heavy metal with adverse impacts ranging from slight alterations of biochemical and physiological systems to serious damage in some vital organs leading to death of the organism (Gagan et al., 2012). It is among the most common heavy metals that cause toxicity to animals and humans (Roberts, 1999). Lead contamination globally has been reported to be due to the increase in its circulation in soil, water, and air as a result of human activities related to industries, food and smoking, drinking water, and other domestic sources (Nriagu and Pacnya, 1988; WHO, 2010b). Levels of lead in the blood that were initially thought to be safe have now been proven to

\footnotetext{
*Corresponding Author

Tajudeen O. Obafemi, Biochemistry Programme, Department of Chemical Sciences, Afe Babalola University, Ado-Ekiti, Nigeria.

E-mail: oobafemi@abuad.edu.ng
}

compromise health and cause injury to multiple organs even while overt symptoms are not present (WHO, 2010a).

Lead binds the sulfhydryl groups present in antioxidants and antioxidant enzymes, which are its most susceptible targets (Hultberg et al., 2001) and further depresses glutathione levels by inactivating glutathione-related antioxidant enzymes. It also renders superoxide dismutase and catalase inactive (Ahamed and Siddiqui, 2007). Other deleterious effects of lead include reducing the synthesis of hemoglobin by inhibiting various key enzymes involved in the heme synthesis pathway and also reducing the life span of circulating erythrocytes by increasing the fragility of cell membranes. The combined aftermath of these two processes leads to anemia (Guidotti et al., 2008).

The harmful effects of lead on hematopoietic, renal, reproductive, and central nervous system are mediated mainly through the increased oxidative stress (Kalia and Flora, 2005) which represents a disparity between the production of free radicals and the ability of biological systems to readily abstract the 
reactive intermediates or to repair the resulting damage (Blokhina et al., 2003). However, antioxidants are substances which, when present at low concentrations as compared to that of the oxidizable substrate, can prevent the oxidation of that substrate (Pietta, 2000). Studies have shown that antioxidants have the capacity to prevent and cure the damage caused by the generation of free radicals in the body (Pietta, 2000).

Synsepalum dulcificum is a shrub that grows up to 20 feet high in its native habitat but does not usually grow higher than 10 feet in cultivation (Wiersema and Leon, 1999). Preliminary studies on the leaves of the plant show that the leaves are very rich source of phytosterol (Chen et al., 2010). The major flavonol pigments present in S. dulcificum fruit are quercetin-3monogalactoside, kaempferol-3-monoglucoside, kaempferol, and myricetin (Buckmire and Francis, 1976). The antidiabetic potential of both the methanolic and flavonoid-rich extracts of $S$. dulcificum in Wistar albino rats was earlier reported in our lab (Obafemi et al., 2017). However, the protective effect of both methanol and flavonoid-rich leaf extracts of $S$. dulcificum on leadinduced toxicity in the liver and kidney of rats has not been fully elucidated.

\section{MATERIALS AND METHODS}

\section{Chemicals and reagents}

Reduced glutathione and epinephrine were purchased from Santa Cruz Biotechnology, Heidelberg, Germany. 1-chloro2,4-dinitrobenzene was purchased from Sigma Chemical Co. (St. Louis, MO). Kits for urea, creatinine, aspartate aminotransferase (AST), alanine aminotransferase (ALT), alakaline phosphatase (ALP), and total protein were obtained from Randox laboratories, Antrim, UK. All other reagents used were of analytical grade.

\section{Plant collection and extraction}

Synsepalum dulcificum (leaves) were obtained from a farmland in Ibadan, Nigeria. The leaves were authenticated in the herbarium of Botany Department University of Ibadan. A voucher number-UIH-22457 was obtained for the leaf. The leaves were afterward cleaned, air-dried, and blended. The blended leaves were extracted with $80 \%$ methanol for 72 hours. The methanolic extract was concentrated using a rotary evaporator, freeze dried, and preserved for the further use.

\section{Preparation of flavonoid-rich extract}

A $3 \mathrm{~g}$ of methanolic extract was, thereafter, dissolved in $20 \mathrm{ml}$ of $10 \% \mathrm{H}_{2} \mathrm{SO}_{4}$ in a small flask and was hydrolyzed by heating on a water bath for 30 minutes at $100^{\circ} \mathrm{C}$. The mixture was placed on ice for 15 minutes, so as to allow flavonoids aglycones precipitate. The cooled solution was filtered and the filtrate (flavonoids aglycone mixture) was dissolved in $50 \mathrm{ml}$ of warm $95 \%$ ethanol $\left(50^{\circ} \mathrm{C}\right)$, the resulting solution was again filtered into 100 -ml volumetric flask which was made up to the mark with $95 \%$ ethanol. The filtrate collected was concentrated to dryness using rotary evaporator (Chu et al., 2002).

\section{Experimental design}

A total of 45 Wistar albino rats $(180 \pm 20 \mathrm{~g})$ were acclimatized to laboratory conditions for a period of 1 week and they had access to feed and water ad libitum. Animal studies adhered to the Principles of Laboratory Animal Care (NIH publication \#85-23, revised in 1985). Ethical clearance (approval no: ABUAD-SCI04/03/15/013) was obtained for the study from the university's ethical committee. The animals were, thereafter, randomly distributed into nine groups of five animals each as follows:

Group 1: Control (distilled water only)

Group 2: Lead-induced (50 mg/kg Lead acetate only)

Group 3: $50 \mathrm{mg} / \mathrm{kg}$ Lead acetate $+25 \mathrm{mg} / \mathrm{kg}$ methanolic leaf extract (MSD)

Group 4: $50 \mathrm{mg} / \mathrm{kg}$ Lead acetate $+50 \mathrm{mg} / \mathrm{kg}$ MSD

Group 5: $50 \mathrm{mg} / \mathrm{kg}$ Lead acetate $+80 \mathrm{mg} / \mathrm{kg}$ MSD

Group 6: $50 \mathrm{mg} / \mathrm{kg}$ Lead acetate $+25 \mathrm{mg} / \mathrm{kg}$ flavonoid-rich leaf extract (FSD)

Group 7: $50 \mathrm{mg} / \mathrm{kg}$ Lead acetate $+50 \mathrm{mg} / \mathrm{kg}$ FSD

Group 8: $50 \mathrm{mg} / \mathrm{kg}$ Lead acetate $+80 \mathrm{mg} / \mathrm{kg}$ FSD

Group 9: $50 \mathrm{mg} / \mathrm{kg}$ Lead acetate $+40 \mathrm{mg} / \mathrm{kg}$ vitamin C

\section{Preparation of samples and biochemical analyses}

After 14 days of treatment, rats were euthanized and blood was collected through cardiac puncture. Serum was, thereafter, obtained by centrifuging the blood sample for 10 minutes at 3,000 rpm. Liver and kidney were excised from experimental animals, rinsed in ice-cold normal saline, and homogenized in five volumes of ice-cold 0.1-M Tris-HCL buffer, $\mathrm{pH}$ 7.4. AST, ALT, and ALP levels were estimated in kidney and liver; urea and creatinine levels were estimated in serum, while total protein level was estimated in both serum and tissues all by following the instructions from Randox kits manufacturer. Lipid peroxidation (LPO) was estimated using the method of Vashney and Kale (1990). Glutathione S-transferase activity was measured using the method of Habig et al. (1974), Superoxide dismutase activity was measured using the method of Misra and Fridovich (1972).

\section{Hematological study}

Blood sample for hematological study was collected through cardiac puncture into heparinized tubes and were immediately used for the determination of hematological parameters. Total red blood cell (RBC) and white blood cell (WBC) counts were estimated according to the visual method of Dacie and Lewis (1991). The percentage packed cell volume (PCV) was determined according to the hematocrit method, while the blood hemoglobin $(\mathrm{Hb})$ concentration in all samples was estimated according to the cyanomethemoglobin method using Drabkin's reagent.

\section{Histopathological study}

Liver and kidney tissues of animals were used for histopathological study. Tissues were fixed in $10 \%$ buffered formalin, routinely processed, and embedded in paraffin wax. Sections were cut on glass slides at a thickness of $4 \mu \mathrm{m}$ and stained with hematoxylin and eosin (Culling, 1974). The slides were examined under a light microscope with $\times 400$ magnification. 


\section{Statistical analysis}

Results were expressed as mean value \pm standard error of mean (SEM). Data analysis was done using Graphpad prism5 software by one-way analysis of variance followed by Turkey-test. $p<0.05$ (95\% confidence limit) was considered to be statistically significant.

\section{RESULT}

Table 1 shows that the lead-induced group had a significantly $(p<0.05)$ lower serum total protein than both the control- and extract-treated groups. However, the creatinine and urea levels of the lead-induced group was significantly $(p<0.05)$ higher than all the other groups in the study, except the group treated with $25 \mathrm{mg} / \mathrm{kg}$ FSD whose urea level was significantly higher than the control- and extract-treated groups.

In Table 2, significantly $(p<0.05)$ lower hepatic total protein, ALT, AST, and ALP levels were observed in the leadinduced group when compared with other groups. Conversely, the lead-induced group showed a significantly $(p<0.05)$ higher malondialdehyde (MDA) levels when compared with other groups in the study. The glutathione-s-transferase (GST) and superoxide dismutase (SOD) activity was significantly $(p<0.05)$ lower in the lead-induced group than both the control- and ascorbic acid-treated groups. However, a regular pattern of GST and SOD activity was not observed in the liver of extract-treated groups.

Table 3 shows that the lead-induced group had a significantly $(p<0.05)$ lower kidney level of total protein and AST than the other groups in the study. Furthermore, the control group and almost all the other groups in the study had a significantly $(p<0.05)$ higher kidney levels of ALT and ALP than the leadinduced group. The kidney GST activity in the lead-induced group and groups treated with lower doses of MSD was significantly $(p<0.05)$ lower than in the control and other groups in the study, while the control and all the treated groups showed a significantly $(p<0.05)$ higher kidney SOD activity than the lead-induced group.

Table 4 shows that the PCV and hemoglobin level of lead-induced group was significantly $(p<0.05)$ lower than that of the control and both extracts and ascorbic-acid treated groups except the group treated with $25 \mathrm{mg} / \mathrm{kg}$ MSD. In addition, the leadinduced group had a significantly $(p<0.05)$ higher WBC than all other groups in the study. The RBC of the lead-induced group was significantly $(p<0.05)$ lower than the control. However, apart

Table 1. The effect of MSD and FSD on total protein, creatinine, and urea in serum of Wistar albino rats administered lead.

\begin{tabular}{cccc}
\hline Groups & Total protein $(\mathbf{g} / \mathbf{d l})$ & Creatinine $(\boldsymbol{\mu m o l} / \mathbf{l})$ & Urea $(\mathbf{m g} / \mathbf{d l})$ \\
\hline Group 1 & $7.18 \pm 0.11$ & $3.11 \pm 0.06$ & $81.88 \pm 8.15$ \\
Group 2 & $4.79 \pm 0.13^{*}$ & $6.11 \pm 0.01^{*}$ & $153.74 \pm 1.85^{*}$ \\
Group 3 & $9.30 \pm 0.17$ & $0.19 \pm 0.02$ & $113.08 \pm 7.03$ \\
Group 4 & $9.39 \pm 0.56$ & $0.11 \pm 0.01$ & $128.67 \pm 5.74$ \\
Group 5 & $8.02 \pm 0.38$ & $0.13 \pm 0.01$ & $112.52 \pm 4.09$ \\
Group 6 & $7.02 \pm 0.24$ & $1.45 \pm 0.02$ & $137.03 \pm 4.61$ \\
Group 7 & $6.98 \pm 0.26$ & $1.41 \pm 0.02$ & $65.73 \pm 19.31$ \\
Group 8 & $7.08 \pm 0.14$ & $1.08 \pm 0.05$ & $97.48 \pm 4.40$ \\
Group 9 & $8.46 \pm 0.31$ & $1.26 \pm 0.02$ & $59.05 \pm 18.23$ \\
\hline
\end{tabular}

Each value is a mean of five determinations \pm SEM. Values with *in the same column are significantly $(p<0.05)$ different from the control.

Group 1 = Control; group 2 = Lead-induced; group $3=$ lead $+25 \mathrm{mg} / \mathrm{kg} \mathrm{MSD}$; group $4=1$ lead $+50 \mathrm{mg} / \mathrm{kg} \mathrm{MSD}$; group $5=$ lead $+80 \mathrm{mg} / \mathrm{kg} \mathrm{MSD}$; group $6=$ lead $+25 \mathrm{mg} / \mathrm{kg} \mathrm{FSD}$; group $7=$ lead $+50 \mathrm{mg} / \mathrm{kg} \mathrm{FSD}$; group $8=1$ ead $+80 \mathrm{mg} /$ $\mathrm{kg} \mathrm{FSD}$; and group $9=1$ ead $+40 \mathrm{mg} / \mathrm{kg}$ ascorbic acid.

Table 2. The effect of MSD and FSD on biochemical parameters in liver of Wistar albino rats administered lead.

\begin{tabular}{|c|c|c|c|c|c|c|c|}
\hline Groups & $\begin{array}{l}\text { Total protein } \\
\text { (g/dl) }\end{array}$ & $\operatorname{AST}(\mathbf{U} / \mathbf{I})$ & $\operatorname{ALP}(\mathbf{U} / \mathbf{I})$ & $\operatorname{ALT}(\mathbf{U} / \mathbf{I})$ & $\begin{array}{c}\text { MDA } \\
\left(\times 10^{4} \mathrm{nmol} / \mathrm{ml}\right)\end{array}$ & $\begin{array}{c}\text { GST } \\
(\mu \mathrm{mol} / \mathrm{minutes} / \mathrm{mg} \text { protein })\end{array}$ & $\begin{array}{c}\text { SOD } \\
\text { (U/mg protein) }\end{array}$ \\
\hline Group 1 & $1.17 \pm 0.04$ & $73.60 \pm 12.58$ & $126.41 \pm 12.27$ & $48.44 \pm 0.94$ & $5.45 \pm 1.53$ & $0.8 \pm 0.02$ & $7.08 \pm 1.25$ \\
\hline Group 2 & $0.86 \pm 0.03^{*}$ & $9.50 \pm 1.07^{*}$ & $56.86 \pm 5.13^{*}$ & $30.24 \pm 1.79^{*}$ & $14.01 \pm 1.24^{*}$ & $0.5 \pm 0.03^{*}$ & $4.17 \pm 0.00^{*}$ \\
\hline Group 3 & $1.46 \pm 0.07$ & $25.68 \pm 4.20$ & $77.83 \pm 16.33$ & $35.76 \pm 0.56$ & $7.67 \pm 2.35$ & $0.7 \pm 0.01$ & $2.08 \pm 0.33^{*}$ \\
\hline Group 4 & $1.65 \pm 0.14$ & $48.60 \pm 8.15$ & $69.55 \pm 7.63$ & $34.48 \pm 0.53$ & $4.03 \pm 1.75$ & $0.4 \pm 0.00^{*}$ & $6.25 \pm 0.87$ \\
\hline Group 5 & $1.92 \pm 0.56$ & $25.60 \pm 3.25$ & $120.30 \pm 8.32$ & $33.36 \pm 0.58$ & $3.40 \pm 1.45$ & $0.3 \pm 0.01^{*}$ & $6.25 \pm 0.00$ \\
\hline Group 6 & $1.92 \pm 0.56$ & $25.70 \pm 4.59$ & $102.67 \pm 7.34$ & $36.52 \pm 0.32$ & $4.33 \pm 1.59$ & $0.5 \pm 0.01^{*}$ & $1.04 \pm 0.00^{*}$ \\
\hline Group 7 & $1.66 \pm 0.54$ & $42.30 \pm 9.98$ & $109.85 \pm 7.05$ & $35.52 \pm 0.67$ & $6.92 \pm 1.98$ & $0.6 \pm 0.02$ & $2.71 \pm 0.26^{*}$ \\
\hline Group 8 & $1.92 \pm 0.07$ & $17.60 \pm 5.20$ & $70.10 \pm 9.24$ & $47.68 \pm 0.56$ & $4.42 \pm 2.22$ & $0.3 \pm 0.02^{*}$ & $6.67 \pm 0.63$ \\
\hline Group 9 & $2.76 \pm 1.01$ & $36.10 \pm 7.61$ & $107.09 \pm 8.76$ & $38.88 \pm 2.06$ & $6.28 \pm 2.70$ & $0.7 \pm 0.04$ & $8.96 \pm 2.83$ \\
\hline
\end{tabular}

Each value is a mean of five determinations \pm SEM. Values with " in the same column are significantly $(p<0.05)$ different from the control.

Group 1 = Control; group 2 = Lead-induced; group $3=$ lead $+25 \mathrm{mg} / \mathrm{kg} \mathrm{MSD}$; group $4=$ lead $+50 \mathrm{mg} / \mathrm{kg} \mathrm{MSD}$; group $5=$ lead $+80 \mathrm{mg} / \mathrm{kg} \mathrm{MSD}$; group $6=$ lead $+25 \mathrm{mg} / \mathrm{kg} \mathrm{FSD}$; group $7=$ lead $+50 \mathrm{mg} / \mathrm{kg} \mathrm{FSD}$; group $8=1$ ead $+80 \mathrm{mg} / \mathrm{kg} \mathrm{FSD}$; and group $9=1$ ead $+40 \mathrm{mg} / \mathrm{kg}$ ascorbic acid. 
Table 3. The effect of MSD and FSD on biochemical parameters in kidney of Wistar albino rats administered lead.

\begin{tabular}{cccccccc}
\hline Groups & $\begin{array}{c}\text { Total protein } \\
(\mathbf{g} / \mathbf{d} \mathbf{l})\end{array}$ & AST $(\mathbf{U} / \mathbf{I})$ & ALP $(\mathbf{U} / \mathbf{I})$ & ALT $(\mathbf{U} / \mathbf{I})$ & $\begin{array}{c}\text { MDA } \\
(\times \mathbf{1 0} \mathbf{n m o l} / \mathbf{m l})\end{array}$ & $\begin{array}{c}\text { GST } \\
(\boldsymbol{\mu m o l} / \mathbf{m i n u t e s} / \mathbf{m g} \text { protein) }\end{array}$ & $\begin{array}{c}\text { SOD } \\
(\mathbf{U} / \mathbf{m g} \mathbf{~ p r o t e i n})\end{array}$ \\
\hline Group 1 & $1.70 \pm 0.16$ & $49.90 \pm 1.74$ & $23.81 \pm 3.77$ & $29.12 \pm 2.81$ & $1.83 \pm 0.53$ & $0.36 \pm 0.03$ & $28.00 \pm 1.22$ \\
Group 2 & $0.52 \pm 0.52^{*}$ & $32.10 \pm 4.57^{*}$ & $7.04 \pm 2.36^{*}$ & $12.24 \pm 6.19^{*}$ & $2.82 \pm 1.97^{*}$ & $0.16 \pm 0.14^{*}$ & $20.00 \pm 0.00^{*}$ \\
Group 3 & $2.35 \pm 0.33$ & $52.60 \pm 2.16$ & $18.40 \pm 1.33$ & $18.88 \pm 4.22^{*}$ & $1.37 \pm 2.11$ & $0.18 \pm 0.03^{*}$ & $38.00 \pm 4.14$ \\
Group 4 & $3.95 \pm 0.94$ & $48.00 \pm 1.81$ & $14.07 \pm 2.16$ & $22.44 \pm 7.08$ & $0.90 \pm 1.59$ & $0.18 \pm 0.04^{*}$ & $44.00 \pm 6.05$ \\
Group 5 & $4.45 \pm 0.57$ & $71.90 \pm 2.98$ & $16.78 \pm 0.54$ & $42.36 \pm 3.15$ & $1.05 \pm 2.64$ & $0.27 \pm 0.04$ & $26.00 \pm 1.87$ \\
Group 6 & $2.77 \pm 0.89$ & $66.30 \pm 3.45$ & $7.04 \pm 1.84^{*}$ & $41.32 \pm 8.32$ & $3.85 \pm 1.01^{*}$ & $0.26 \pm 0.04$ & $35.00 \pm 7.25$ \\
Group 7 & $1.98 \pm 0.09$ & $59.50 \pm 3.76$ & $7.04 \pm 0.66^{*}$ & $33.84 \pm 2.72$ & $2.32 \pm 0.10$ & $0.30 \pm 0.02$ & $45.00 \pm 9.87$ \\
Group 8 & $2.53 \pm 0.22$ & $45.20 \pm 1.83$ & $19.48 \pm 7.33$ & $40.92 \pm 3.96$ & $1.57 \pm 0.51$ & $0.23 \pm 0.02$ & $42.00 \pm 5.54$ \\
Group 9 & $2.03 \pm 0.08$ & $59.70 \pm 1.50$ & $7.58 \pm 1.33^{*}$ & $29.08 \pm 9.75$ & $1.58 \pm 0.37$ & $0.31 \pm 0.01$ & $28.00 \pm 5.15$ \\
\hline
\end{tabular}

Each value is a mean of five determinations \pm SEM. Values with "in the same column are significantly $(p<0.05)$ different from the control.

Group 1 = Control; group $2=$ Lead-induced; group $3=1$ ead $+25 \mathrm{mg} / \mathrm{kg} \mathrm{MSD}$; group $4=$ lead $+50 \mathrm{mg} / \mathrm{kg} \mathrm{MSD}$; group $5=1$ ead $+80 \mathrm{mg} / \mathrm{kg} \mathrm{MSD}$

group $6=$ lead $+25 \mathrm{mg} / \mathrm{kg} \mathrm{FSD}$; group $7=$ lead $+50 \mathrm{mg} / \mathrm{kg} \mathrm{FSD}$; group $8=$ lead $+80 \mathrm{mg} / \mathrm{kg}$ FSD; and group $9=1$ ead $+40 \mathrm{mg} / \mathrm{kg}$ ascorbic acid

Table 4. The effect of MSD and FSD on some hematological parameters in Wistar albino rats after lead administration.

\begin{tabular}{ccccc}
\hline Group & PCV $(\mathbf{\%})$ & WBC $(\times \mathbf{1 0}$ / $/ \mathbf{l})$ & RBC $\left(\times \mathbf{1 0} \mathbf{1}^{\mathbf{2}} / \mathbf{l}\right)$ & Hemoglobin $(\mathbf{g} / \mathbf{d})$ \\
\hline Group 1 & $42.60 \pm 1.50$ & $2640.00 \pm 92.74$ & $3.90 \pm 0.24$ & $14.18 \pm 0.49$ \\
Group 2 & $32.20 \pm 1.46^{*}$ & $3140.00 \pm 87.18^{*}$ & $3.50 \pm 0.20^{*}$ & $10.70 \pm 0.49^{*}$ \\
Group 3 & $34.20 \pm 1.53^{*}$ & $2640.00 \pm 67.82$ & $3.10 \pm 0.07^{*}$ & $11.36 \pm 0.15^{*}$ \\
Group 4 & $40.40 \pm 1.50$ & $2800.00 \pm 93.47$ & $3.50 \pm 0.18^{*}$ & $13.42 \pm 0.50$ \\
Group 5 & $37.20 \pm 1.86$ & $2800.00 \pm 7071$ & $3.80 \pm 0.10$ & $12.37 \pm 0.61$ \\
Group 6 & $35.20 \pm 2.06$ & $2860.00 \pm 92.74$ & $3.60 \pm 0.18$ & $11.70 \pm 0.68$ \\
Group 7 & $40.80 \pm 0.80$ & $2780.00 \pm 37.42$ & $3.92 \pm 0.04$ & $13.58 \pm 0.26$ \\
Group 8 & $38.00 \pm 0.63$ & $2860.00 \pm 50.99$ & $3.88 \pm 0.18$ & $12.64 \pm 0.21$ \\
Group 9 & $37.60 \pm 1.29$ & $2760.00 \pm 50.99$ & $3.62 \pm 0.17$ & $12.50 \pm 0.42$ \\
\hline
\end{tabular}

Each value is a mean of five determinations \pm SEM. Values with *in the same column are significantly $(p<0.05)$ different from the control.

Group 1 = Control; Group 2 = Lead-induced; group $3=\mathrm{Lead}+25 \mathrm{mg} / \mathrm{kg} \mathrm{MSD}$; group $4=\mathrm{Lead}+50 \mathrm{mg} / \mathrm{kg} \mathrm{MSD}$; group $5=\mathrm{Lead}+80 \mathrm{mg} / \mathrm{kg} \mathrm{MSD}$; group $6=\mathrm{Lead}+25 \mathrm{mg} / \mathrm{kg} \mathrm{FSD}$; group $7=\mathrm{Lead}+50 \mathrm{mg} / \mathrm{kg} \mathrm{FSD}$; group $8=\mathrm{Lead}+80 \mathrm{mg} /$ $\mathrm{kg} \mathrm{FSD}$; and group $9=\mathrm{Lead}+40 \mathrm{mg} / \mathrm{kg}$ ascorbic acid.

from the groups treated with lower doses of MSD, all the other groups had a significantly $(p<0.05)$ higher RBC than the leadinduced group.

Figures $1 \mathrm{a}, \mathrm{c}, \mathrm{e}, \mathrm{f}, \mathrm{g}, \mathrm{h}$, and i have no visible lesion. Figure 1d shows mild cellular reactions around the portal vessel, while Figure $1 \mathrm{~b}$ shows portal congestion and cellular reactions around the portal vessels.

Figures $2 \mathrm{a}, \mathrm{c}, \mathrm{d}, \mathrm{e}, \mathrm{f}, \mathrm{g}, \mathrm{h}$, and i have no visible lesion. Figure $2 \mathrm{~b}$ shows degenerated epithelia and shrunken tubules.

\section{DISCUSSION}

Lead is a ubiquitous environmental and industrial pollutant that has been detected in nearly all phases of environment and biological system. Its persistence in human and animal tissues has quite often been associated with considerable health risks (Juberg et al., 1997). Ascorbic acid is probably the most widely studied vitamin when it comes to the prevention of lead-induced oxidative stress. Its property of quenching ROS along with metal chelation makes it a potential detoxifying agent for lead (Das and Saha, 2010). However, the therapeutic and prophylactic use of plant extracts to ameliorate lead-induced organ damage has been severally explored (Adikwu et al., 2013).
Total protein level is not only a rough measure of protein status but also reflects major functional changes in kidney and liver functions (Leena et al., 2011). Moreover, $\mathrm{Pb}^{2+}$ disturbs intracellular $\mathrm{Ca}^{2+}$ homeostasis (Simons, 1993) and damage the endoplasmic reticulum, which results in decrease in protein synthesis (Kumari et al., 1990). In the result presented in Table 1, a significantly $(p<0.05)$ lower serum protein level was observed in the leadinduced group when compared with the control and both the extract and vitamin $\mathrm{C}$-treated groups. This implies that the extracts might be able to prevent the disruption of $\mathrm{Ca}^{2+}$ homeostasis and damaging effect of lead on the endoplasmic reticulum, thereby improving protein synthesis.

Urea is the major nitrogen-containing metabolic product of protein metabolism. The levels of urea and creatinine in serum are used as indicators of the renal function (Renugadevi and Prabu, 2010). Moreover, in a previous study, increased serum creatinine level was used as a diagnostic marker of the renal failure (Donadio et al., 1997). In the result shown in Table 1, serum urea and creatinine levels of control and both the extract and vitamin C-treated groups were significantly $(p<0.05)$ lower than the lead-induced group. The administration of both MSD and 


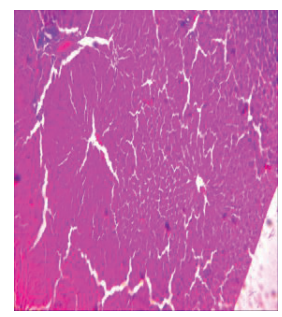

1a

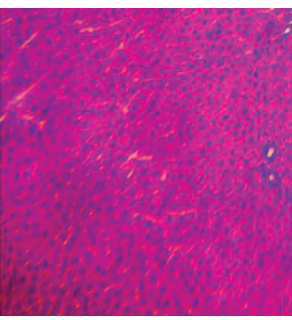

$1 \mathrm{e}$

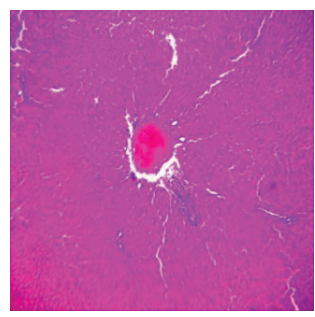

$1 b$

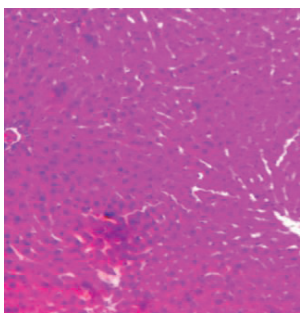

1f

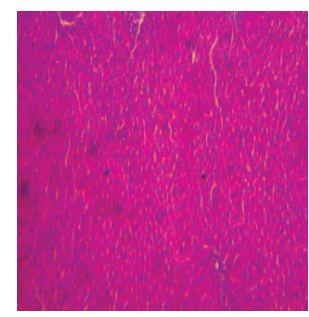

$1 \mathrm{c}$

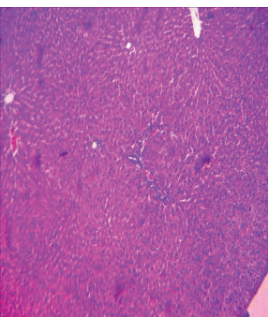

$\lg$

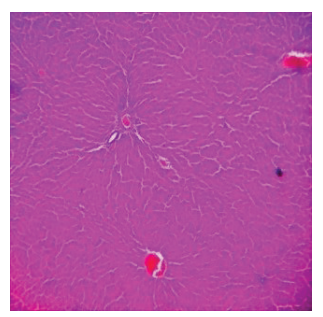

$1 d$

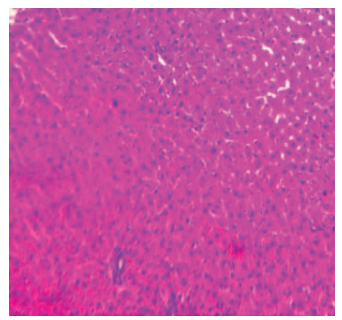

$1 \mathrm{~h}$

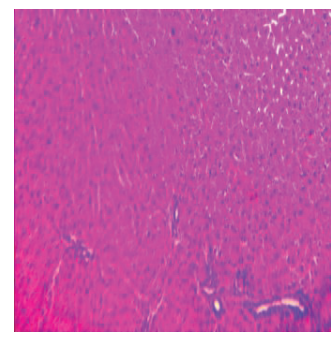

$1 \mathrm{i}$

Figure 1. Liver sections of lead-acetate administered Wistar albino rats after treatment with MSD and FSD. (a, c, e, f, g, h, and i) Have no visible lesion. (d) Mild cellular reactions around the portal vessel, while (b) portal congestion and cellular reactions around the portal vessels. (a) Control, (b) Lead-induced, (c) Lead $+25 \mathrm{mg} / \mathrm{kg} \mathrm{MSD}$, (d) Lead + $50 \mathrm{mg} / \mathrm{kg} \mathrm{MSD}$, (e) Lead + $80 \mathrm{mg} / \mathrm{kg} \mathrm{MSD,} \mathrm{(f)} \mathrm{Lead} \mathrm{+} 25 \mathrm{mg} / \mathrm{kg} \mathrm{FSD,} \mathrm{(g)} \mathrm{Lead} \mathrm{+} 50 \mathrm{mg} / \mathrm{kg} \mathrm{FSD}$, (h) Lead $+80 \mathrm{mg} / \mathrm{kg} \mathrm{FSD}$, and (i) Lead $+40 \mathrm{mg} / \mathrm{kg}$ ascorbic acid.

FSD evidently protects kidney function from lead intoxication as indicated by significant reduction of serum urea and creatinine in the extract and ascorbic acid-treated groups. It is worthy of note that groups treated with MSD had the lowest creatinine levels when compared with the control, FSD, and vitamin C-treated groups.

Liver synthesizes proteins and the decrease in the total protein levels in liver could be attributed to changes in protein and free amino acids metabolism and their synthesis in the liver (Gaskill et al., 2005). In the result presented in Table 1 , the lead-induced group had a significantly $(p<0.05)$ lower total protein level than both the control and treated groups. This adverse effect might be caused by the interference of lead with protein synthesis or by the binding of lead to some metal binding proteins and their removal through detoxification processes (Yousef, 2004).
AST, ALT, and ALP are enzymes that are usually located in the cytosol and mitochondria where they are involved in the transfer of amino group from $\alpha$-amino to $\alpha$-keto acids (Chapatwala et al., 1982). They are normally localized within the cells of liver, heart, kidney, and muscles (Wells et al., 1986). Tables 2 and 3 show the levels of these enzymes in the liver and kidney, respectively. Lead is known to produce oxidative injury in organs by increasing peroxidation of membrane lipids (Yiin and Lin, 1995), resulting in the loss of functional integrity of membrane architecture. Liver injury, following lead exposure, is well characterized by the elevated levels of hepatic marker enzymes in serum which indicate cellular leakage and loss of functional integrity of hepatic membrane architecture (Atef et al., 2013). We, therefore, propose that the observed significant $(p<0.05)$ decreased level of these enzymes in the liver of lead-induced group might be as a result of leakage of substantial amount of the enzymes into the serum as a 


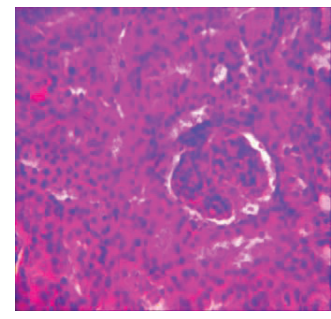

$2 \mathrm{a}$

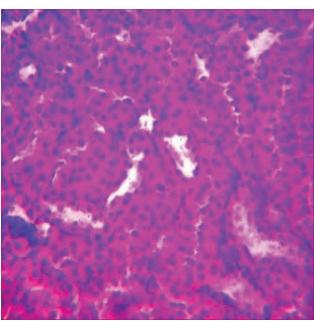

$2 \mathrm{e}$

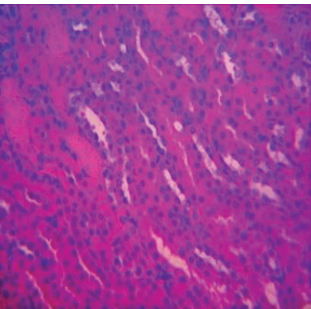

$2 \mathrm{i}$

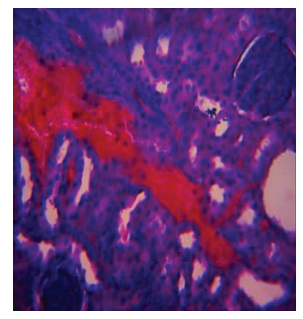

$2 b$

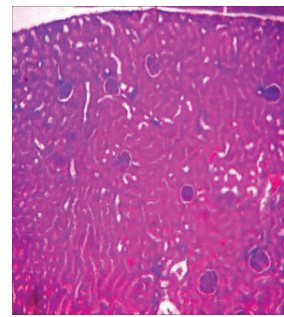

$2 \mathrm{f}$

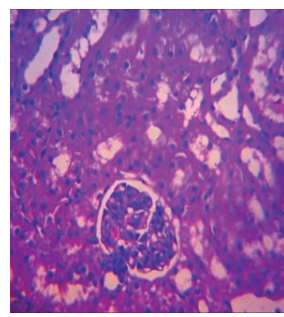

$2 \mathrm{c}$

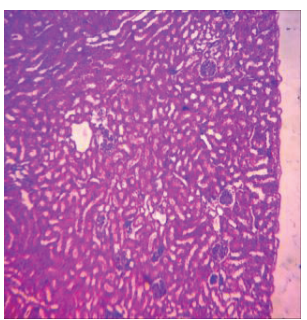

$2 \mathrm{~g}$

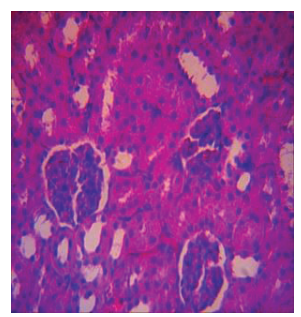

$2 d$

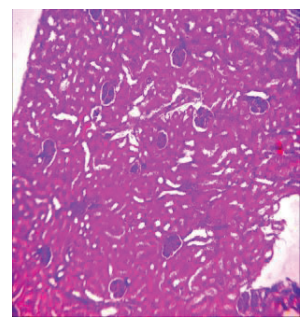

$2 \mathrm{~h}$

Figure 2. Kidney sections of lead-acetate administered Wistar albino rats after treatment with MSD and FSD. (a) Control, (b) Lead-induced, (c) Lead + $25 \mathrm{mg} / \mathrm{kg} \mathrm{MSD,} \mathrm{(d)} \mathrm{Lead}+50 \mathrm{mg} / \mathrm{kg} \mathrm{MSD}$, (e) Lead + $80 \mathrm{mg} / \mathrm{kg} \mathrm{MSD}$, (f) Lead + 25 mg/kg FSD, (g) Lead + $50 \mathrm{mg} / \mathrm{kg} \mathrm{FSD,} \mathrm{(h)} \mathrm{Lead} \mathrm{+} 80 \mathrm{mg} / \mathrm{kg} \mathrm{FSD}$, and (i) Lead + $40 \mathrm{mg} / \mathrm{kg}$ ascorbic acid.

result of loss of functional integrity of membranes in these organs. This is in contrast to the control, extracts, and vitamin C-treated groups which showed higher levels of the enzymes. This may imply that the treatment effectively prevented the leakage of the enzymes into the serum.

Lead-induced hepatic and renal damage is mostly rooted in LPO and disturbance of the prooxidant-antioxidant balance by generation of reactive oxygen species (Bechara, 2004). LPO, a reactive oxygen species mediated mechanism, has been implicated in the pathogenesis of various liver injuries and subsequent liver fibrogenesis in experimental animals and humans (Mervat et al., 2012; Niemela et al., 1995). The ability of lead to induce LPO is predicated on its strong affinity for thiol groups of amino acids, especially cysteine. Lead may, therefore, affect the antioxidant defense via inhibiting the functional thiol groups of enzymes, such as SOD and GST (Jurczuk et al., 2006; Patrick, 2006). This fact might be the reason for the significantly $(p<0.05)$ lower SOD and GST levels in the kidney of lead-induced animals when compared with the other groups as shown in Table 3. However, from the result presented in Table 2, a clear pattern of SOD and GST activities were not observed in the liver of experimental animals. We, therefore, suppose that the observed lower MDA level in the liver of control and treated groups, which is a clear indication of the ability of antioxidant enzymes to prevent peroxidation in the tissue, might be as a result of the activities of other antioxidant enzymes which were not evaluated in this study.

Furthermore, MDA level is an important marker of LPO in biological systems. Lead is known to produce oxidative damage in the liver by enhancing peroxidation of lipid membranes (Chaurasia and Kar, 1997) and LPO is deleterious process solely carried out by free radicals (Halliwell and Gutteridge, 1989). Tables 2 and 3 show that the MDA levels in the liver and kidney, respectively, of experimental animals administered lead-acetate. We observed that MDA level in the lead-induced group was significantly $(p<0.05)$ higher in both the liver and kidney than all the other groups in this study except renal tissue that was treated 
with the lowest dose of FSD $(25 \mathrm{mg} / \mathrm{kg})$ which did not show a significantly $(p<0.05)$ lower MDA level than the lead-induced. This observation suggests that the extracts may have a protective effect against the peroxidative activity of lead in biological systems. This corroborates the findings of other authors (Sharma and Pandey, 2010).

Table 4 presents the effect of MSD and FSD treatment on hematological parameters in lead-induced toxicity in rats. The exposure to lead significantly decreases red blood cell counts, hemoglobin levels, and hematocrit values in rats (Terayama, 1993). According to Manser et al. (1990), low-level exposure to inorganic lead in workplace can have harmful effect on certain types of the blood cells, reduce hemoglobin production, and cause reduced lifespan and function of red blood cells. Erythrocytes have a high affinity for lead, binding $99 \%$ of the lead in the bloodstream (Pratap, 2014). The damaging effect of lead on the erythrocytes membrane could result in hemolysis or decrease of blood iron level which may be the reason of decreasing concentration of $\mathrm{Hb}$ and PCV (Topashka-Ancheva et al., 2003). Lead has also been reported to significantly affect the heme synthesis pathway by downregulating three key enzymes involved in the synthesis of heme, especially $\delta$-aminolevulinic acid dehydratase (ALAD) (Piomelli, 2002). Moreover, its effect on ALAD has been used clinically to gauge the degree of lead poisoning. These effects of lead on erythrocyte and its inhibition on heme biosynthetic process may contribute to the significantly $(p<0.05)$ low PCV, RBC, and hemoglobin levels in the lead-induced group when compared with the other groups in the study. This situation was, however, reversed in the extracts and reference drug treated-groups even though the lower doses of MSD did not show much effect in this regard. We also observed that the lead-induced group has a significantly ( $p<$ 0.05 ) higher level of WBC than all the other groups in the study. This might be due to the increased inflammatory response as a result of lead toxicity of which WBCs are a major component. This result is in agreement with those described by Bersenyi (2003) and Simsek et al. (2009).

Figures 1 and 2 are histopathological examinations of liver and kidney of experimental animals used in the present study. In Figure 1, it was observed that the liver of lead-induced group showed portal congestion and cellular reactions around the portal vessels. This is likely due to the toxicity effect of lead-acetate on the liver architecture of the animals. However, no significant lesion was observed in the liver section of other groups in the study. Furthermore, as shown in Figure 2, the kidney section of lead-induced group showed degenerated epithelia and shrunken tubules. No significant lesion was, however, observed in the other groups. The absence of lesions in the organs of control and treated groups may imply that flavonoid-rich extract of $S$. dulcificum leaves has a protective effect on the organs. These observations corroborate the results obtained from biochemical parameters.

\section{CONCLUSION}

From the results obtained in this present study, it could be safely concluded that both MSD and FSD has appreciable protective effect on the liver and kidney against lead-acetateinduced toxicity in Wistar albino rats. This might be due to the antioxidant activity of the extract which has been confirmed in an earlier study. There is, however, a need for further study so that the molecular mechanism of the observed protective effect and the actual active principles in the extract could be delineated.

\section{FINANCIAL SUPPORT}

None.

\section{CONFLICT OF INTEREST}

\author{
Nil.
}

\section{REFERENCES}

Adikwu E, Deo O, Geoffrey, OBP, Enimeya DA. Lead organ and tissue toxicity: roles of mitigating agents (Part 1). Br J Pharmacol Toxicol, 2013; 4(6):232-40.

Ahamed M, Siddiqui MKJ. Low level Lead exposure and oxidative stress: current opinions. Clin Chim Acta, 2007; 383:57-64.

Atef M. Attia M, Fatma A, Ibrahim A, Nabil GM, Aziz SW. Antioxidant effects of ginger (Zingiber officinale Roscoe) against lead acetate-induced hepatotoxicity in rats. Afr J Pharm Pharmacol, 2013; $7(20): 1213-9$

Bechara EJH. Lead poison and oxidative stress Free Radic Biol Med, 2004; 36:22.

Bersenyi A, Fekete S, Szoes Z. Effect of ingested heavy metals $(\mathrm{Cd}, \mathrm{Pb}$ and $\mathrm{Hg})$ on haematology and serum biochemistry in rabbits. Acta Vet Hung, 2003; 51:297-304.

Blokhina O, Virolainen E, Fagerstedt KV. Antioxidants, oxidative damage and oxygen deprivation stress: review. Ann Bot, 2003; 91:179-94.

Buckmire RE, Francis FJ. Anthocyanins and flavonols of miracle fruit. J Food Sci, 1976; 41:1363-65.

Chapatwala KD, Boykin M, Butts A, Rajanna B. Effect of intraperitoneally injected cadmium on renal and hepatic gluconeogenic enzymes in rats. Drug Chem Toxicol, 1982; 5:305-17.

Chaurasia SS, Kar A. Protective effect of vitamin E against Lead induced deterioration of membrane associated type I iodothyronine 5'-monodeiodinase (5'D-I) activity in male mice. Toxicology, 1997; 124:203-9.

Chen CY, Wang YD, Wang HM. Chemical constituents from the leaves of Synsepalum dulcificum. Chem Nat Compd, 2010; 46:495.

Chu YF, Sun J, Wu X., Liu RH. Antioxidant and antiproliferative activity of common vegetables. J Agric Food Chem, 2002; 50:6910-6.

Culling CFA. Handbook of histochemical histopathological techniques. 3rd edition, Butterworth, London, UK, pp 29-61, 1974.

Dacie JV, Lewis SM. Practical haematology. 7th edition, Churchill Livingstone, Edinburgh, UK, pp 521-534, 1991.

Das KK, Saha S. L-ascorbic acid and alpha tocopherol supplementation and antioxidant status in Nickel- or Lead-exposed rat brain tissue. J Basic Clin Physiol Pharmacol, 2010; 21:325-46.

Donadio C, Lucchesi A, Tramonti G, Bianchi C. Creatinine clearance predicted from body cell mass is a good indicator of renal function. Kidney Int Suppl, 1997; 63:166-8.

Gagan F, Deepesh G, Archana T. Toxicity of lead: a review with recent updates. Interdiscip Toxicol, 2012; 5(2):47-58.

Gaskill CL, Miller LM, Mattoon JS. Liver histopathology and liver and serum alanine aminotransferase and alkaline phosphatase activities in epileptic dogs receiving phenobarbital. Vet Pathol, 2005; 42(2):147-60.

Guidotti TL, McNamara J, Moses MS. The interpretation of trace element analysis in body fluids. Indian J Med Res, 2008; 128:524-32.

Habig WH, Pabst MJ, Jakoby WB. Glutathione S-transferases. The first enzymatic step in mercapturic acid formation. J Biol Chem, 1974; 249(22):7130-9.

Halliwell B, Gutteridge JM, Free radical in biology and medicine. Protection against oxidants in biological systems: the superoxide theory of oxygen toxicity, Clarendon Press, Oxford, UK, pp 86-123, 1989. 
Hultberg B, Andersson A, Isaksson A. Interaction of metals and thiols in cell damage and glutathione distribution: potentiation of mercury toxicity by dithiothreitol. Toxicology, 2001; 156:93-100.

Juberg DR, Kleiman CF, Simona CK. Position paper of the American Council on Science and Health: Lead and human health. Ecotoxicol Environ Saf, 1997; 38:162-80.

Jurczuk M, Moniuszko-Jakoniuk J, Brzóska MM. Involvement of some low-molecular thiols in the peroxidative mechanisms of lead and ethanol action on rat liver and kidney. Toxicology, 2006; 219:11-21.

Kalia K, Flora SJ. Strategies for safe and effective therapeutic measures for chronic arsenic and lead poisoning. J Occup Health, 2005; 47:1-21.

Kumari SS, Verghese A, Muraleedharan D, Menon UP. Protective action of aspirin in experimental myocardial infarction induced by isoproterenol in rats and its effect on lipid peroxidation. Indian J Exp Biol, 1990; 28:480-5.

Leena K, Veena S, Arti S, Shweta L, Sharma SH. Protective role of coriandrum sativum (coriander) extracts against lead nitrate induced oxidative stress and tissue damage in the liver and kidney in male mice. Int J Appl Biol Pharm, 2011; 2(3):65-83.

Manser, WR, Lalini R, Haider S, Khan MA. Trace element studies on Karachi population, Part-V, Blood Lead levels in normal healthy adults and grammar's School children. Int J Mod Phys, 1990; 40(7):150-3.

Mervat HG, Nabela IE, Mohamed MAH, Gihan GM. Efficacy of Curcumin on Lead Induced Nephrotoxicity in Female Albino Rats. J Am Sci, 2012; 8(6):502-10.

Misra HP, Fridovich I. The generation of superoxide radical during the antioxidant of hemoglobin. J Biol Chem, 1972; 247:6960-2.

Niemela O, Parkkila S, Herttuala SY, Halsted C, Witztum JL, Lanca A, Israel Y. Covalent protein adducts in the liver as a result of ethanol metabolism and lipid peroxidation. Lab Invest, 1995; 70:537-46.

Nriagu JO, Pacnya JM. Quantitative assessment of worldwide contamination of air, water and soils by trace metals. Nature, 1988; 333:134-9.

Obafemi TO, Akinmoladun AC, Olaleye MT, Onasanya A. Antidiabetic potential of methanolic and flavonoid-rich extracts of Synsepalum dulcificum leaves in type 2 diabetic rats. J Ayurveda Integr Med, 2017; 8(4):238-46.

Patrick L. Lead toxicity part II. The role of free radical damage and the use of antioxidants in the pathology and treatment of lead toxicity. Altern Med Rev, 2006; 11(2):114-27.

Pietta PG. Flavonoids as antioxidants. J Nat Prod, 2000; 63:1035-42.

Piomelli S. Childhood lead poisoning. Pediatr Clin North Am, 2002; 49:1285-304.

Pratap M. Lead toxicity on hematological changes and amelioration with ginger (Zingiber officinale) extract in male albino rats. Int J Adv Res, 2014; 2:23-8.

Renugadevi J, Prabu SM. Cadmium-induced hepatotoxicity in rats and the protective effect of naringenin. Exp Toxicol Pathol, 2010; 62:171-81

Roberts JR. Metal toxicity in children. Training manual on pediatric environmental health; putting it into practice. Children's Environmental Health Network/Public Health Institute, Maryland, Washington, D.C, USA, 1999
Sharma V, Pandey D. Protective role of Tinospora cordifolia against lead-induced hepatotoxicity. Toxicol Int, 2010; 17(1):12-7.

Simons T. Lead-calcium interactions in cellular lead toxicity. Neurotoxicology, 1993; 14:77-86.

Simsek N, Karadeniz A, Kalkan Y, Keles ON, Unal B. Spirulina platensis feeding inhibited the anemia- and leucopenia-induced Lead and Cadmium in rats. J Hazard Mater, 2009; 164:1304-9.

Terayama K. Effects of Lead on electrophoretic mobility, membrane sialic acid, deformability and survival of rat erythrocytes. Ind Health, 1993; 31:113-26.

Topashka-Ancheva M, Metcheva R, Teodorova S. Bioaccumulation and damaging action of polymetal industrial dust on laboratory mice Mus musculus alba II. Genetic, cell and metabolic disturbances. Environ Res, 2003; 92:152-60.

Wells RM, Meintyre RH, Morgan AK, Davies PS. Physiological Stress Responses in Big Game Fish after exposure: observation on plasma chemistry and blood factors. Comp Biochem Physiol, 1986; 64:565-71.

World Health Organization. Childhood lead poisoning. WHO Document Production Services, Geneva, Switzerland, 2010a.

World Health Organization. Public health and environment. WHO Document Production Services, Geneva, Switzerland, 2010b.

Vashney R, Kale RK. Effect of calmodulin antagonists on radiation induced lipid peroxidation in microsomes. Int J Rad Biol, 1990; $58: 733-43$.

Wiersema JH, Leon B. World economic plants: a standard reference. CRC Press, Boca Raton, FL, p 661, 1999.

Yiin SJ, Lin TH. Lead-catalyzed peroxidation of essential unsaturated fatty acid. Biol Trace Elem Res, 1995; 50:167-72.

Yousef MI. Aluminium-induced changes in hematobiochemical parameters, lipid peroxidation and enzyme activities of male rabbits: protective role of ascorbic acid. Toxicology, 2004; 199:47-57.

How to cite this article:

Obafemi TO, Onasanya A, Adeoye A, Falode JA, Daniel DJ, Irefo EF, Ojo AO, Fadaka A, Afolabi OB, Awe JO, Omiyale BO. Protective effect of methanolic and flavonoid-rich leaf extracts of Synsepalum dulcificum (Danielli) on lead-acetateinduced toxicity in Wistar albino rats. J Appl Pharm Sci, 2019; 9(05):065-072. 